\title{
Roles of Exogenous Technologies in Vehicle Innovation: Cases from a Japan's Automotive Parts Manufacturing Firm
}

\author{
Masahiro Nakagawa \\ Tokyo City University, Japan \\ Chihiro Watanabe \\ University of Jyvaskyla, Finland
}

\begin{abstract}
This paper explores the roles of technological innovations in the growth of Japan's motor vehicle industry, mainly from technology spillover perspective from the early 2000s to today. An empirical analysis focusing on business performances, $R \& D$ investments, and patent applications taking a noteworthy unique case in Japan was attempted. Empirical analyses on the productivity of patent to technology stock, use of exogenous technologies for their own technological innovation on its Automotive Business Unit elucidated that innovation capabilities, incorporation of exogenous technologies, and profit generation makes a virtuous cycle of continuous technological innovation. Furthermore, we found that the range of technology spillovers is not only expanding along with the development of information communication technology, but also superposing itself intricately between organizational (industryfirm-business unit) layers.
\end{abstract}

Keywords: Technological innovation; technology spillover; exogenous technology; motor vehicle industry; Japan; automotive manufacturing.

\section{INTRODUCTION}

Since the beginning of this millennium, development of network technologies and service economies has changed socio-economic systems and lifestyles. In addition, the collapse of the Internet bubble in 2001, the financial crisis in 2008, and the Great East Japan Earthquake in 2011 also acted as important turning points. Paralleled by them, Japan's industrial structure has also changed. "Electric machinery, equipment, and supplies industry (in short, EMI)" has lost their top position and "Motor vehicles, parts and accessories industry (in short, MVI)" has replaced them. Along with this structural change, automotive parts manufacturing firms have developed new products and technologies, mainly in the field of environmental and info-communication technologies. (Hybrid) electric vehicles and automatic driving are good examples.

These changes in Japan's leading industries have been studied in detail. Cortez et al. analyzed how MVI invoked a virtuous cycle with environmental investment and sales, while EMI adopted a risk averse strategy because of their accumulated losses (Cortez et al., 2011). Also, Bergek et al. reported that

Journal of Technology Management for Growing Economies Vol. 8, No. 1 April 2017 pp. 93-112

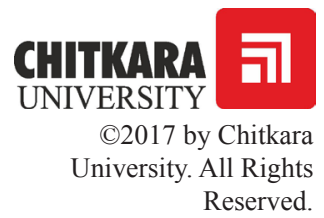


Nakagawa, M. Watanabe, $\mathrm{C}$. growth in MVI was attributable to its eco-friendly policy initiatives (Bergek et al., 2014); Volpato et al. concluded that MVI had developed with the adoption of ICT supported supply chains (Volpato et al., 2002). Kato et al. explored the productivity of Keiretsu and independent parts suppliers in MVI (Kato et al., 2016). Yun reported an analysis of technological development, business models, and markets (Yun et al., 2016). Nakamura et al. discussed platform business strategies of leading MVI manufacturers (Nakamura et al., 2006). Ruff pointed out that managerial foresight is important for strategic innovation of MVI (Ruff, 2015).

More generally, Peters et al. analyzed German automotive manufacturers and suppliers and clarified that technology spillovers between manufacturers and suppliers were strategically important for realizing innovations (Peters et al., 1997). Crispeels et al. demonstrated that open innovation played important roles in $\mathrm{R} \& \mathrm{D}$ on electric and hybrid electric vehicles (Crispeels et al., 2016). Hall et al. analyzed Canadian biotechnology firms from R\&D and innovation perspective and resulted that innovation (new products introductions) is associated with business performance (Hall et al., 2002).

Bernstein demonstrated that intra- and interindustry technology spillovers decreased production costs and enhanced returns (Bernstein, 1988). Veugelers analyzed Flemish R\&D active firms and found that $R \& D$ cooperation with external firms played significant positive effect on internal R\&D (Veugelers, 1997).

It is a truism that open innovation and technology spillover enforce technological innovation (Chesbrough, 2003, Belderbos et al., 2004, Christensen, 2005, Beneito, 2006, Bartel et al., 2007, Dosi et al., 2010, Arora et al., 2016, Battke et al., 2016, Konno, 2016). Grillitsh et al. analyzed Austrian automotive suppliers' technological innovation; demonstrated that innovative firms were combining knowledge from different sources and channels (Grillitsh et al., 2014). Grillitsch et al. also presented that more innovative firms tended to exploit external sources, and that R\&D cooperations and in-house knowledge capability were both important (Grillitsch et al., 2015). Bloom et al. compared technology spillovers (positive) and technology steal (negative); showed positive effects dominated (Bloom et al., 2013).

Among these, Nakagawa et al. analyzed roles of technology spillover in the evolution of technological innovation, focusing on activities inside a company (Nakagawa et al., 2007, 2009, 2010, $2010^{2}$ ).

In line with above mentioned background, it can easily be supposed that the amazing growth of Japan's motor vehicle industry owes to technological innovations, mainly to technology spillovers from other industries. This

Journal of Technology Management for Growing Economies, Volume 8, Number 1, April 2017 
paper explores the roles of technological innovations in the growth of Japan's motor vehicle industry, mainly from technology spillover perspective from the early 2000 s to today.

\section{FRAMEWORK OF THE ANALYSES}

Considering the discussions so far, we generate three questions about technological innovations in automotive parts manufacturing firms. Given that those manufacturing firms have grown with technological innovations, have such firms maintained high capability to create technological innovation? If such innovations are, to some extent, due to incorporation of exogenous technologies, how and how much are they incorporating exogenous technology? To explore these questions, this paper will empirically analyze innovation dynamism of automotive technologies by focusing on activities in an individual firm.

\section{Selection of cases}

Aiming at conducting the foregoing analyses, a case analysis taking Sumitomo Electric Industries, Ltd. (SEI), particularly their automotive business unit (AMB) was attempted with the following reasons:

The first reason concerns its business domains. As shown in Table1, SEI has 5 business units: Automotive business unit (AMB), info-communication business unit (ICB), Electronics business unit (ELB), Environment and Energy business unit (ENB), and Industrial materials business unit (IMB). Particularly, AMB was initiated in 1949; its first deal was to make wire harnesses (in-vehicle electric wires) for U.S. forces in Japan. In 1963, SEI commenced disc brake operations (transferred to Aisin Seiki in 2007); and in 1998 it entered the car electronics domain.

Table 1: SEI's business units and main products (2014)

\begin{tabular}{|l|l|}
\hline \multicolumn{1}{|c|}{$\begin{array}{c}\text { Business } \\
\text { Units }\end{array}$} & \multicolumn{1}{c|}{ Main Products } \\
\hline Automotive & $\begin{array}{l}\text { wire harness, vibration-proof rubber, hose, electric parts for motor } \\
\text { vehicle, anti-lock brake system, brake pad }\end{array}$ \\
(AMB) & $\begin{array}{l}\text { optical fiber/ cable, telecommunication cable/ device, optical fiber } \\
\text { splicing tool, optical data link, photo-electronics device, access sys- } \\
\text { tem network apparatus (GE-PON, CDN, CATV parts), traffic con- } \\
\text { trol network system, }\end{array}$ \\
\hline $\begin{array}{l}\text { Info-commu } \\
\text { nication }\end{array}$ & $\begin{array}{l}\text { electric wire for electric equipment, compound semiconductor ma- } \\
\text { terials, metal materials for electronics parts, electron beam irradiat- } \\
\text { ed products, flexible printed circuit, fluororesin products }\end{array}$ \\
\hline Electronics & (ELB)
\end{tabular}

Journal of Technology Management for Growing Economies, Volume 8, Number 1, April 2017 
Nakagawa, M. Watanabe, C.

\begin{tabular}{|l|l|}
\hline \multicolumn{1}{|c|}{$\begin{array}{c}\text { Business } \\
\text { Units }\end{array}$} & \multicolumn{1}{c|}{ Main Products } \\
\hline $\begin{array}{l}\text { Environment } \\
\text { and Energy } \\
\text { (ENB) }\end{array}$ & $\begin{array}{l}\text { wire rod, power line/ cable and apparatus, magnet wire, aircraft fuel } \\
\text { tank, construction and engineering (power cable) }\end{array}$ \\
\hline $\begin{array}{l}\text { Industrial } \\
\text { Materials } \\
\text { (IMB) }\end{array}$ & $\begin{array}{l}\text { PC steel cord, steel cord, cemented carbide, diamond and CBN } \\
\text { tools, optical parts for laser processing, sintered parts, heat dissipa- } \\
\text { tion substrate for semiconductor }\end{array}$ \\
\hline
\end{tabular}

(Data from Sumitomo Electric Industries, Ltd. (1994-2015, annually) Financial Statement)

In addition, trends in sales, operating income, and $R \& D$ expenditures suggest that AMB represents SEI's business mainstreams. As shown in Figures 1,2, and 3, AMB has maintained the highest sales among other business units throughout the whole period observed. The superior performance of SEI's AMB in terms of operating income testifies to successful release of new network electronics and eco-friendly products, as shown in Table 2.

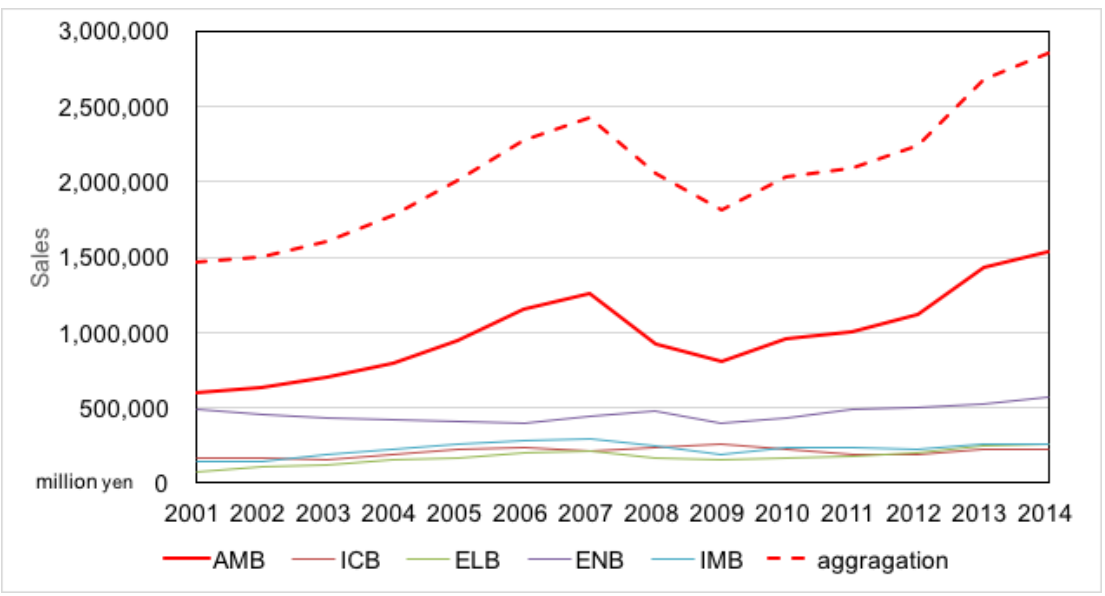

Figure 1: Trends in SEI's sales by business unit (2001-2014)

(Data from Sumitomo Electric Industries, Ltd. (1994-2015, annually) Financial Statement)

Journal of Technology Management for Growing Economies, Volume 8, Number 1, April 2017 


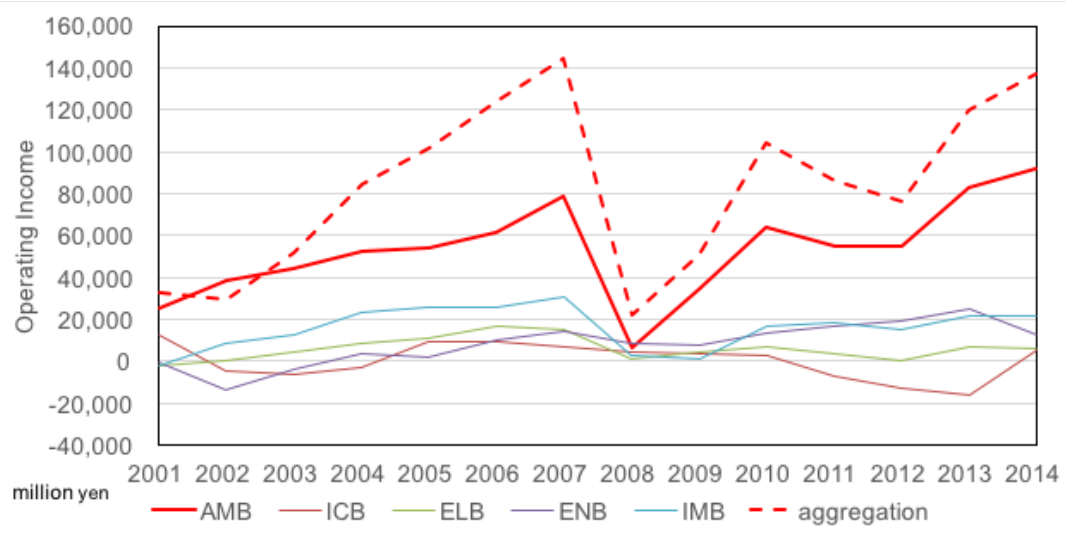

Roles of

Exogenous

Technologies in

Vehicle

Figure 2: Trends in SEI's operating income by business unit (fiscal 20012014)

(Data from Sumitomo Electric Industries, Ltd. (1994-2015, annually)

Financial Statement)

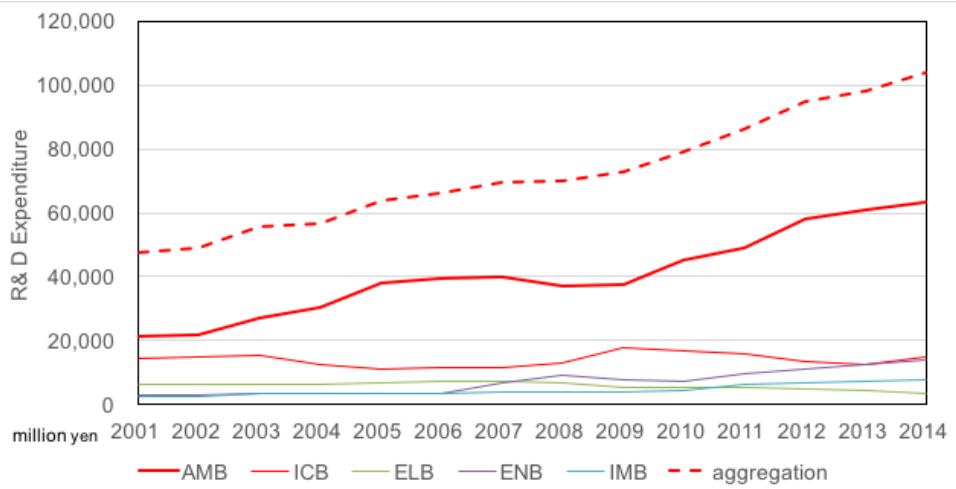

Figure 3: Trends in SEI's R\&D expenditures by business unit (fiscal 20012014)

(Data from Sumitomo Electric Industries, Ltd. (1994-2015, annually) Financial Statement)

Table 2: Major new technologies and products released by SEI's AMB

$$
\text { (2001-2014) }
$$

\begin{tabular}{|l|l|l|}
\hline & Network and electronics & $\begin{array}{l}\text { (Hybrid) electric vehicle, } \\
\text { environment }\end{array}$ \\
\hline 2001 & -Blind corner monitor camera & \\
\hline
\end{tabular}




\begin{tabular}{|c|c|c|c|c|}
\hline \multirow[t]{2}{*}{$\begin{array}{l}\text { Nakagawa, M. } \\
\text { Watanabe, C. }\end{array}$} & & Network and electronics & \multicolumn{2}{|c|}{$\begin{array}{l}\text { (Hybrid) electric vehicle, } \\
\text { environment }\end{array}$} \\
\hline & 2002 & $\begin{array}{l}\text {-High-speed in-vehicle LAN } \\
\text { (demonstration experiment) }\end{array}$ & & \\
\hline \multirow[t]{9}{*}{98} & 2003 & & \multicolumn{2}{|c|}{$\begin{array}{l}\text {-Li-ion battery electrode } \\
\text { materials for HEV } \\
\text {-High-voltage, large } \\
\text { current relays for HEV }\end{array}$} \\
\hline & 2004 & -Video transmission system & \multicolumn{2}{|c|}{$\begin{array}{l}\text {-Lead-free in-vehicle parts } \\
\text { unit }\end{array}$} \\
\hline & 2005 & -Wide-viewing-angle front camera & \multicolumn{2}{|c|}{-Pipe harness for HEV } \\
\hline & 2008 & $\begin{array}{l}\text {-In-vehicle far infrared camera } \\
\text { module } \\
\text {-Road-vehicle-communica- } \\
\text { tion-supported safe-driving sys- } \\
\text { tem (demonstration experiment) }\end{array}$ & \multicolumn{2}{|c|}{$\begin{array}{l}\text {-Tablead for in-vehicle } \\
\text { Li-ion battery } \\
\text {-Magnet wire for HEV } \\
\text { motor }\end{array}$} \\
\hline & 2009 & $\begin{array}{l}\text {-In-vehicle monitoring system with } \\
\text { far infrared camera }\end{array}$ & \multicolumn{2}{|c|}{$\begin{array}{l}\text {-Powder magnetic reac- } \\
\text { tor } \\
\text {-Electric power cable for } \\
\text { HEV } \\
\text {-Magnet wire for EV } \\
\text { motor } \\
\text {-PHV charging cable }\end{array}$} \\
\hline & 2010 & & \multicolumn{2}{|c|}{$\begin{array}{l}\text {-High-frequency powder } \\
\text { magnetic }\end{array}$} \\
\hline & 2011 & & \multicolumn{2}{|c|}{$\begin{array}{l}\text {-Porous metal for PHV } \\
\text { charging cable } \\
\text {-Connecter cable for EV } \\
\text { quick charging }\end{array}$} \\
\hline & & \multicolumn{3}{|c|}{\begin{tabular}{l|l}
-Smart energy system demonstration exper- & \\
iment
\end{tabular}} \\
\hline & 2012 & \multicolumn{3}{|c|}{$\begin{array}{l}\text {-V2H cable, emergency power feeder } \\
\text {-Vehicle-house-road communication system (joint develop- } \\
\text { ment) }\end{array}$} \\
\hline
\end{tabular}

Journal of Technology Management for Growing Economies, Volume 8, Number 1, April 2017 


\begin{tabular}{|l|l|l|}
\hline 2013 & -Connecter with V2H cable \\
\hline \multirow{3}{*}{2014} & $\begin{array}{l}\text {-EV electricity supply platform (joint devel- } \\
\text { charging system }\end{array}$ \\
\cline { 2 - 3 } \\
$\begin{array}{l}\text { opment) } \\
\text {-Road-vehicle cooperation system for Au- } \\
\text { tonomous driving R\&D program }\end{array}$ \\
\hline
\end{tabular}

Roles of

Exogenous

Technologies in

Vehicle

(Data from Sumitomo Electric Industries, Ltd. (April 1993 - March 2015, monthly))

Finally, SEI has been significantly productive in technological innovation in the MVI domains in this Century. As shown in Figure 4, the patent productivity of SEI is higher than similar firms engaged in MVI. High patent productivity reveals intensive activity in technological innovation.

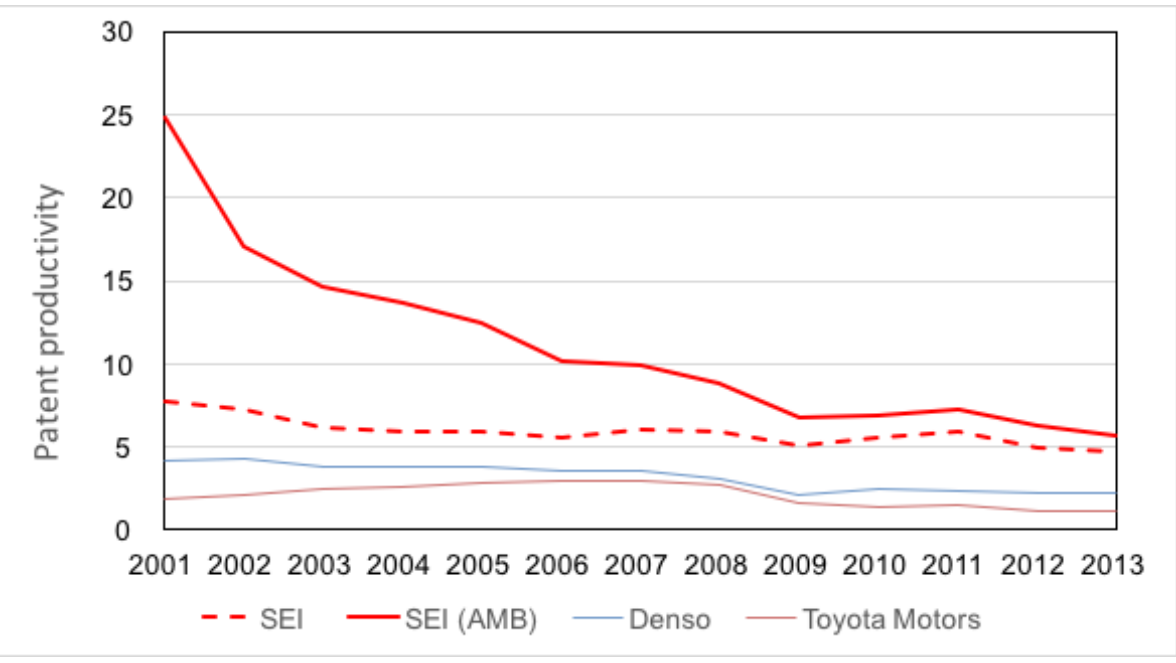

Figure 4: Trends in Patent Productivity of automotive parts manufacturing firms (SEI, AMB/SEI, Denso, Toyota Motors) (2001-2014)

\section{ANALYSES AND RESULTS}

\section{Technology Assimilation Capacity and Profitability}

To elucidate the effects of exogenous technology, let us consider the amount of technology stock that AMB can incorporate from external organizations, and how such technology stocks would contribute to profit. Let us explore its innovation dynamism. 
Nakagawa, M. Watanabe, $\mathrm{C}$.

First, let us estimate technology assimilation capacity of SEI's AMB. Assimilation capacity of a business unit $i$, is formulated as Equations 1 and 2, with technology stock and technology spillover pool of business unit i: $T_{i}$ and $T_{s, i}$ (Watanabe et al., 2002). Calculation of technology stock is demonstrated in Appendix.

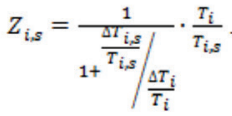

$$
\begin{aligned}
& T_{i, s} \\
& =\sum_{j \neq i} T_{j}
\end{aligned}
$$

Since $\Delta T i / T i=d \ln T i d t$, its integral is expressed as $\ln T i=\Delta T i / T i \mathrm{t}+$ constants. For given $T i$, regression analysis of $\ln T i$ to $t$ gives us $\Delta T i / T i$ as an inclination of t. For technology stock of business unit i presented in Appendix 1, $\Delta T V T i$ and $Z i$ are calculated. Results of regression analyses of $\ln T i$ to $t$ for SEI's AMB, other business units (Not AMB), MVI, and EMI are demonstrated in Table 3.

Table 3: Results of regression analyses of to for SEI's AMB, other business

\begin{tabular}{|c|c|c|c|c|}
\hline & $\Delta T_{i} / \tau$ & \multicolumn{3}{|c|}{ constants } \\
\hline & \multicolumn{2}{|l|}{ Dummy variables } & adj. $R^{2}$ & $D W$ \\
\hline \multirow[t]{2}{*}{ AMB } & $\begin{array}{c}0.12-0.01 D_{2}+0.02 D_{2}-0.052 D_{2} \\
(157.26)--(-6.12)--(6.86)-(-13.02)\end{array}$ & \multicolumn{3}{|c|}{$\begin{array}{c}10.18+0.062 D_{2}-0.25 D_{2}+0.97 D_{2} \\
(3292.97)-(5.88)-(-6.67)-\cdots(12.71)-\end{array}$} \\
\hline & \multicolumn{2}{|c|}{$\begin{array}{l}D_{1}=1 \text { for } 2001 \text { to } 2014,=0 \text { for other years } \\
D_{2}=1 \text { for } 2008 \text { to } 2014,=0 \text { for other years } \\
D_{2}=1 \text { for } 2012 \text { to } 2014,=0 \text { for other years }\end{array}$} & 1.000 & 1.859 \\
\hline \multirow[t]{2}{*}{ Not AMB } & $\begin{array}{c}0.03-0.01 D_{2}-0.01 D_{2} \\
(32.09)^{-}-(-8.65)^{--(-2.85)^{-}}\end{array}$ & \multicolumn{3}{|c|}{$(3196.77)^{-(}(6.67)^{--(2.41)^{-}}$} \\
\hline & \multicolumn{2}{|c|}{$\begin{array}{l}D_{2}=1 \text { for } 2002 \text { to } 2014,=0 \text { for other years } \\
D_{2}=1 \text { for } 2008 \text { to } 2014,=0 \text { for other years }\end{array}$} & 0.996 & 1.823 \\
\hline \multirow[t]{2}{*}{ MVI } & $\begin{array}{c}0.01+0.02 D_{2} \\
(5.57)^{-*}(9.14)^{-}\end{array}$ & \multicolumn{3}{|c|}{$\begin{array}{c}15.96-0.08 D_{2}+0.02 D_{2} \\
(3039.00)-(-9.90)-(5.30)^{-}\end{array}$} \\
\hline & \multicolumn{2}{|c|}{$\begin{array}{c}D_{2}=1 \text { for } 1999 \text { to } 2014,0 \text { for other year } \\
D_{2}=1 \text { for } 2002,2003 \text {, and } 2014,0 \text { for other years }\end{array}$} & 0.098 & 1.709 \\
\hline \multirow[t]{2}{*}{ EMI } & $\begin{array}{c}0.01+0.02 D_{2}-0.02 D_{z} \\
(7.61)-\cdots(14.53) \cdots(-11.52)-\end{array}$ & $\begin{array}{r}15.72-0.1 \\
(456.60)-(-1\end{array}$ & $\begin{array}{l}0.25 D_{2} \\
-(10.85\end{array}$ & $\begin{array}{l}.02 D_{2} \\
(763.44)\end{array}$ \\
\hline & \multicolumn{2}{|c|}{$\begin{array}{l}D_{2}=1 \text { for } 1999 \text { to } 2014,0 \text { for other years } \\
D_{2}=1 \text { for } 2009 \text { to } 2014,0 \text { for other years } \\
D_{2}=1 \text { for } 2001 \text { to } 2014,0 \text { for other years }\end{array}$} & 0.999 & 1.945 \\
\hline
\end{tabular}
units (Not AMB), MVI, and EMI

Journal of Technology Management for Growing Economies, Volume 8, Number 1, April 2017 
Substituting technology stock of business unit i in Ti, technology stock of the other business units inside SEI, industries MVI, and EMI as its technology spillover pools, assimilation capacities of business unit i from these spillover pool can be estimated.

Thus, each of the usable technology stock from AMB (endogenous), Not AMB (in-firm), EMI, and MVI can be estimated (Figure 5).

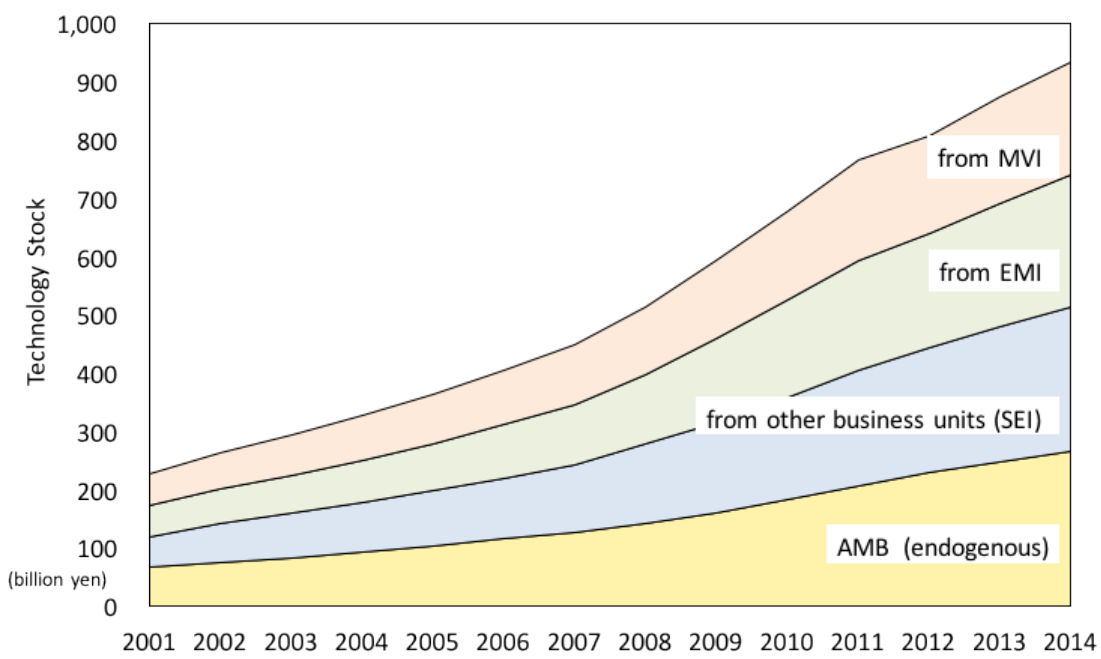

Figure 5. Trends in Usable technology stocks of AMB/SEI (2001-2014).

Figure 5 depicts that AMB has assimilated almost equal amount of technology stock to its endogenous one from Not AMB, MVI, and EMI respectively, and they have been increasing.

Briefly speaking, AMB can use technology stocks from in-firm other business units, ex-firm MVI, and EMI. Here, we can confirm that brisk activity of innovation in AMB can be attributed to usage of a large amount of exogenous technologies.

So far, we have demonstrated that a large amount of usable technology stocks come from outside, and are continuously increasing. So, now, let us discuss the profitability of technology stock.

Marginal productivity of technology (MPT) and internal rate of R\&D's return (IRR) are the indices. MPT and IRR can be demonstrated as functions of technology stock, as expressed in Equations 3-5,

$$
M P T=\frac{\partial S}{\partial T}
$$

$S$ for sales, $T$ for technology stock.

For business unit $i$ with technology stock $T_{i}$, adding the effect of technol-
Roles of

Exogenous

Technologies in

Vehicle 
Nakagawa, M. ogy spillover pool $T_{s, i}$ with assimilation capacity $\mathrm{Z}_{\mathrm{i}}$, MPT can be tranWatanabe, C. $\quad$ scribed to (4):

$$
M P T_{i}=\frac{\partial s_{i}}{\partial\left(T_{i}+Z_{i} \cdot T_{s, i}\right)}
$$

Thus, MPT for endogenous technology stock can be estimated bigger than that for used technology stock.

Similarly, IRR for business unit i $\left(\mathrm{r}_{\mathrm{i}}\right)$ can be developed as (5).

$$
r_{i}=\frac{-\left(1+m_{i} \rho_{i}\right)+\sqrt{\left(1+m_{i} \rho_{i}\right)^{2}-4 m_{i}\left(\rho_{i}-M P T\right)}}{2 m_{i}}
$$

Equation 5 shows that IRR for endogenous technology stock can be estimated bigger than that for used technology stock.

Thus, it is confirmed that exogenous technology stocks incorporated into AMB may boost up its profitability.

\section{Incorporation of exogenous technologies}

As outputs of technological development are patentable, outputs based on collaboration with external researchers are subjected to joint applications. Therefore, tracing joint applications will reveal how external technologies are incorporated.

Patent applications allow us to trace technological innovation in important respects. Inventors and applicants informs us whether the invention was captured in a single organization or not. Claims and specifications give us technological information. Therefore, we can trace trajectories of technological innovation by analyzing patent applications carefully.

First, we collected SEI's 34,073 patent applications (17,164 by AMB) applied to Japan Patent Office, from April 2001 to March 2014. Next, we picked up 29 among them: invented jointly with AMB and other business units, or SEI (AMB) and other firms. Technological relationships among these highlighted four typical cases:

Case 1: development of powder magnetic core

Case 2: development of electricity supply control system for electric vehicles, Case 3: development of road-vehicle communication by optical beacons, Case 4: development of wireless inter-vehicle, vehicle-pedestrian, road-vehicle, and road-pedestrian communication,

\section{Powder magnetic core}

Powder magnetic core is one of the magnetic components in motors and electric circuits. Its technologies are mainly from industrial materials, or chemical technology fields. Conventionally, non-vehicle use cores have been 
constructed from stacked steel plates. However, for in-vehicle use, cores should be lighter in weight and smaller in size. SEI applied manufacturing technology of cemented carbide tools in IMB to develop powder magnetic cores.

SEI applied for 212 patents on this technology from 2003 to 2007. Among these, there were 16 joint applications with Toyota Motors, 3 with Toda Kogyo, 5 with NOF (Nippon Oil and Fats), and 1 with Denso. Thus, this technology is a conversion of inside technology and outside technologies of SEI-AMB. Research on anterior patent applications of these inventors demonstrates what technologies are spilled over from what organizations. From inside, 284 patent applications show that in-vehicle motor technology of AMB and cemented carbide technology of IMB are incorporated. From outside SEI, Toyota motors' and Denso's vehicle parts technologies (MVI) and Toda Kogyo's and NOF's inorganic chemical technologies (Chemical Industry, CMI) are incorporated. In this development, materials technologies of IMB were transferred to vehicle technology of AMB as intra-firm-inter-business unit-inter-technology spillover. Also, inorganic and organic chemical technologies of the chemical industry and electric vehicle technology of MVI were incorporated in AMB as inter-industry-inter-firm-inter-business unit spillovers and intra-business unit-inter-technology spillovers. Figure 6 illustrates the details of technology spillovers of these.
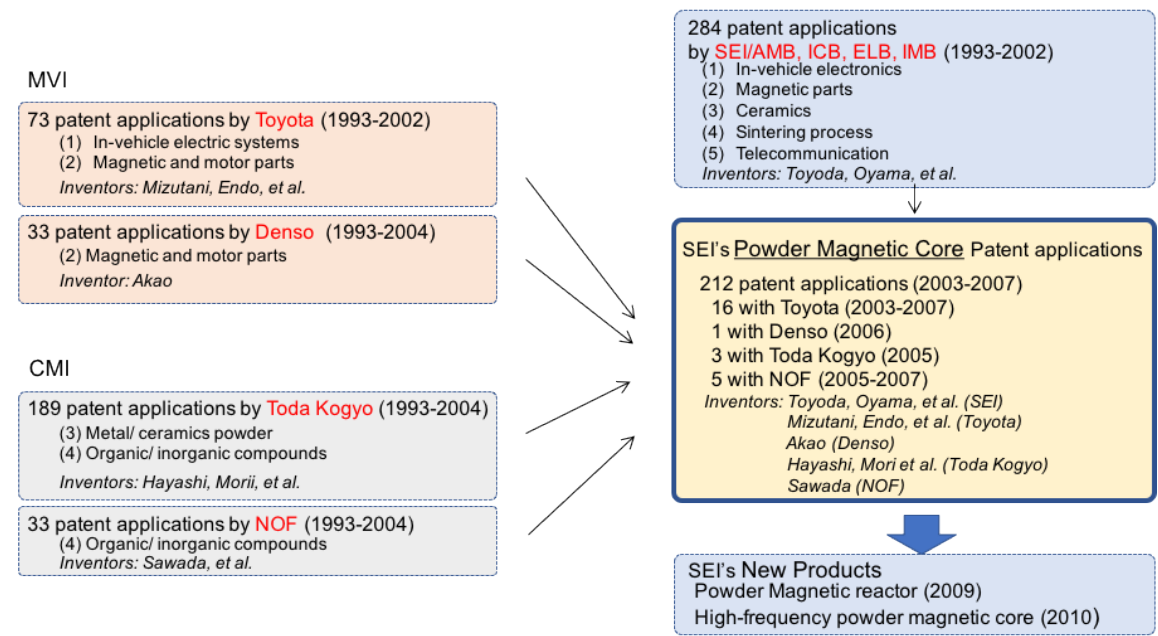

Figure 6: Technology spillovers of powder magnetic core technology Electricity supply system for electric vehicles

Technologies required for electricity supply are associated with 1) measuring electric quantity in a battery and sending its data to power supplying facilities, 2) controlling supply quantity by measuring battery condition, 3) transmitting

Journal of Technology Management for Growing Economies, Volume 8, Number 1, April 2017
Roles of

Exogenous

Technologies in

Vehicle

\section{3}


Nakagawa, M. data and electricity via a single cable. These technologies were claimed in patent Watanabe, C. JPA2012-34208 by three inventors at SEI (Jun-ichi Shirasu, Takashi Yano of ICB, and Ken-ichi Hatanaka of AMB) in 2012. Preceding patent applications are Hatanaka's road-vehicle, inter-vehicle communication technologies (60 applications from 2001 to 2008), electricity supply control technologies by Yano (8 applications from 2008 to 2011), and data communication technologies by Shirasu (28 applications from 2001 to 2011).

What is more interesting is that Shirasu and Yano applied this output to improve electric vehicle supply technologies (Yano, JPA012-28598, JPA2013001977; Shirasu, JPA2014-263718), and electricity control technologies for offices, homes, and communities (Shirasu, JPA2013-199684; Yano, JPA201416470). One may say that those inventors traversed business unit borders to enhance inter-business unit spillovers between AMB and ICB.

As explained above, technology spillovers presented in this case are cross business unit in SEI. Technologies associated with electricity control systems and power line communications are incorporated from ICB to AMB: intrafirm-inter-business unit-inter-technology spillover, as illustrated in Figure 7.

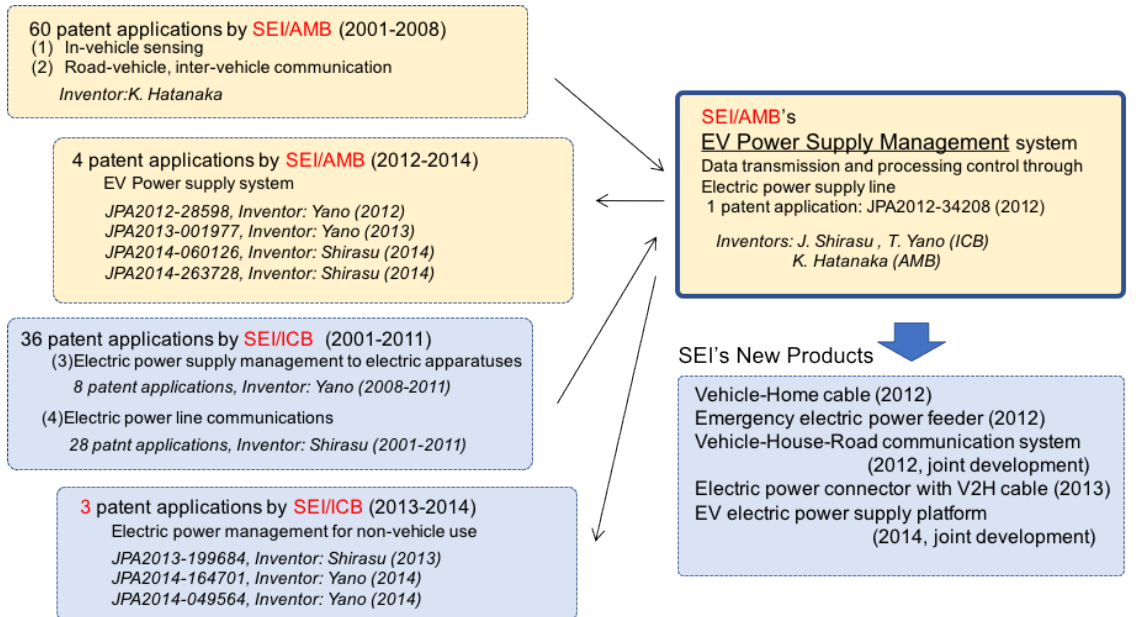

Figure 7: Technology spillovers of electricity supply control technology

Road-vehicle communication by optical beacons

Optical beacons are applied to short distance high-speed communications between a vehicle and its surroundings. About this technology: SEI (AMB) and Omron (EMI) submitted 5 joint patent applications between 2012 to 2014 (JPA2013-31594, JPA2013-40365, JPA2013-86881, JPA2013-272924, JPA2013-272980). Reading their claims, specifications and background arts, we understand these patents consist of sensing technology and communication 
technology. In addition, SEI applied for 54 patents in the years 2001 to 2012 (the same inventors; vehicle sensing and road-vehicle communications domains). Whilst, Omron had applied for 5 patents; again, the same inventors, in the years from 2002 to 2009; in-vehicle road sensors and traffic signal control technology domains. Therefore, we may say that SEI and Omron's previously developed technologies contributed to the new technology. Figure 8 . Shows technology spillovers of optical beacon road-vehicle communication technology.
Roles of

Exogenous

Technologies in

Vehicle
5 patent applications by Omron (2002-2009) In-vehicle road surface sensor

Road-vehicle communication system

Inventor: Y. Miyazaki, T. Okumura, et al.
222 patent applications by SEI/ AMB, ICB (1998-2012)

Inventors: K. Hayama, Y. Taniguchi, et al.

$\downarrow$

SEl's Road-Vehicle Communication technology with optical beacons

5 patent applications JPA2013-31594 (2013)

Inventors: K. Hayama, Y. Taniguchi, K. Miyake, S. Takagi (SEI) Y. Miyazaki, T. Okumura (Omron)

JPA2013-40365 (2013)

Inventor: K. Hayama (SEI)

JPA2013-86881 (2013)

Inventors: K. Hayama, S. Tto (SEI)

JPA2013-272924 (2013)

Inventors: K. Hayama, T. Sato (SEI)

JPA2013-272980 (2013)

Inventors: K. Hayama, T. Sato (SEI)

Figure 8: Technology spillovers of optical beacon road-vehicle communication technology.

Wireless inter-vehicle, vehicle-pedestrian, road-vehicle, and road-pedestrian communication

Wireless communications are applied to data transmission with transportation infrastructures, such as information transportation system (ITS) and the Internet. Their protocols are Wi-Fi or cellular phone data communication (LTE). This case is an example of a communication control system between a base station (road) and a mobile station (vehicle or pedestrian). This new technology can be found in SEI-Panasonic (EMI), and SEI-Sanyo (EMI) joint patent applications (JPA2012-231608, JPA2012-285843) in 2012. These patent applications claim road (pedestrian)-vehicle communication and data processing technologies. Preceding patent applications are many. SEI had applied for 61 patents, credited to the same inventors, on road-vehicle and vehicle-pedestrian communications from 2004 to 2012. Panasonic and Sanyo had applied for a total of 10 patents in the domain of packet communication and cellular phone processing technologies in the years from 2001 to 2012. 2 years after the joint patent applications in 2012, SEI constructed a road-vehicle 
Nakagawa, M. Watanabe, $\mathrm{C}$. cooperation system in a national $R \& D$ program for autonomous driving. Figure 9 summarizes technological development of these.

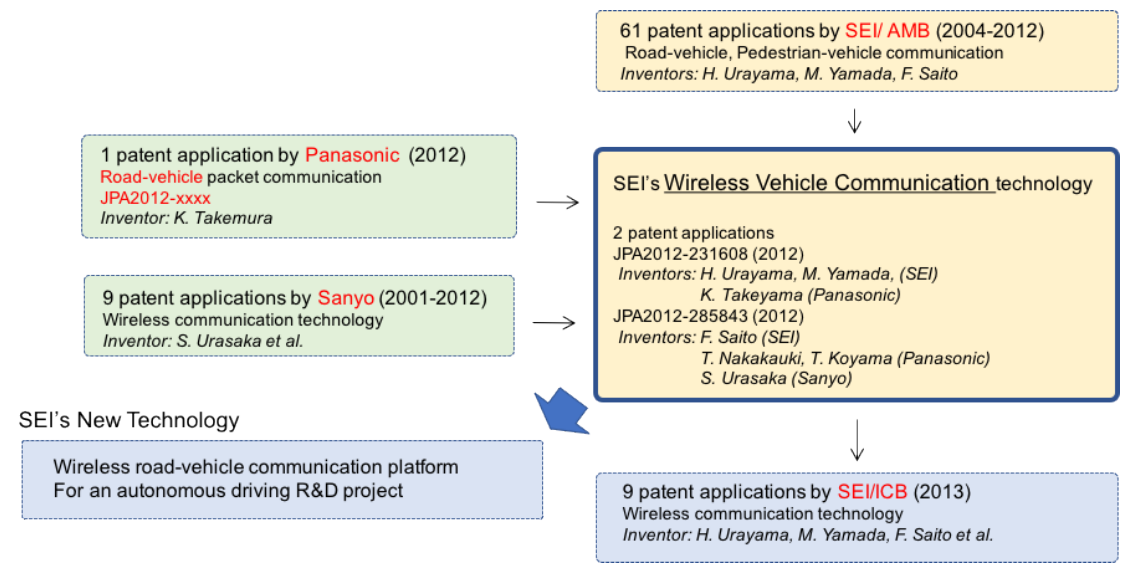

Figure 9: Technology spillovers of wireless vehicle communication technology.

\section{DISCUSSION}

From the foregoing discussions in 2.2, it was established that AMB in SEI is continuously increasing profit in virtue of continuous technology investment and technology spillovers, as outlined in Figure 10.

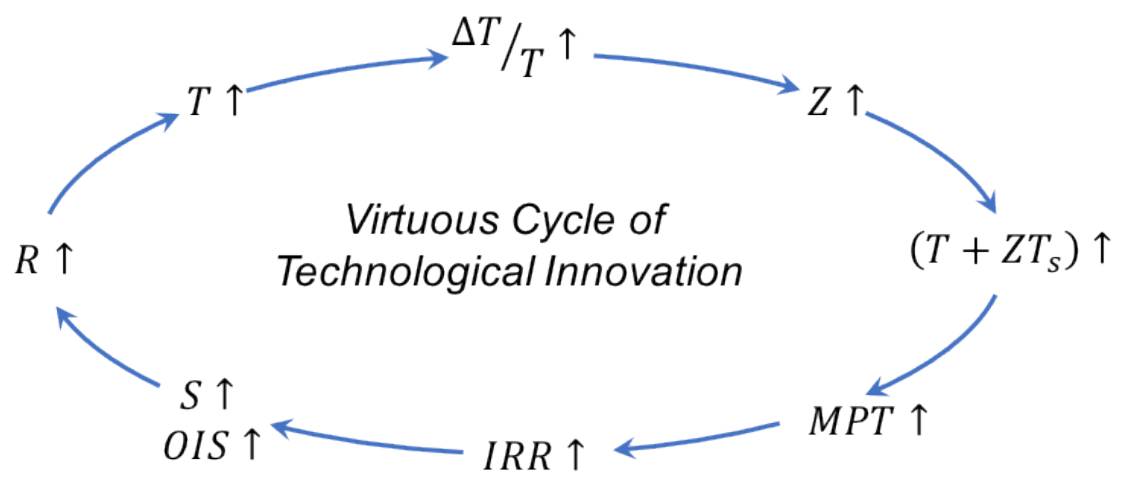

Figure 10: Virtuous cycle of technological innovation.

Specifically, and sequentially, (1) the first step of the virtuous cycle is sufficient investment in R\&D, which increases technology stock, (2) next, increased technology stock boosts the assimilation capacity of exogenous technology, which enforces technological innovation; (3) thus, MPT and IRR for endogenous technology stock increase; (4) this boosts sales and operating

Journal of Technology Management for Growing Economies, Volume 8, Number 1, April 2017 
income; (5) thus, sufficient reinvestment funds are available, which closes the virtuous cycle of technology innovation.

Next, let us consider technology spillovers in organizational and technological terms. Technology spillovers in four cases taken up in this study all play significant roles in incorporating new technologies into automotive innovation. Common characteristics in these four cases are that both interand intra-technology spillovers occurred with inter- and intra- industry, interand intra-firm, and inter- and intra- business unit spillovers. Considering the layered structure of organizations (industry-firm-business unit layers), we may say that technology spillovers occurred simultaneously in multilayered organizations. Figure 11 illustrates superposed technology spillovers analyzed and discussed so far.

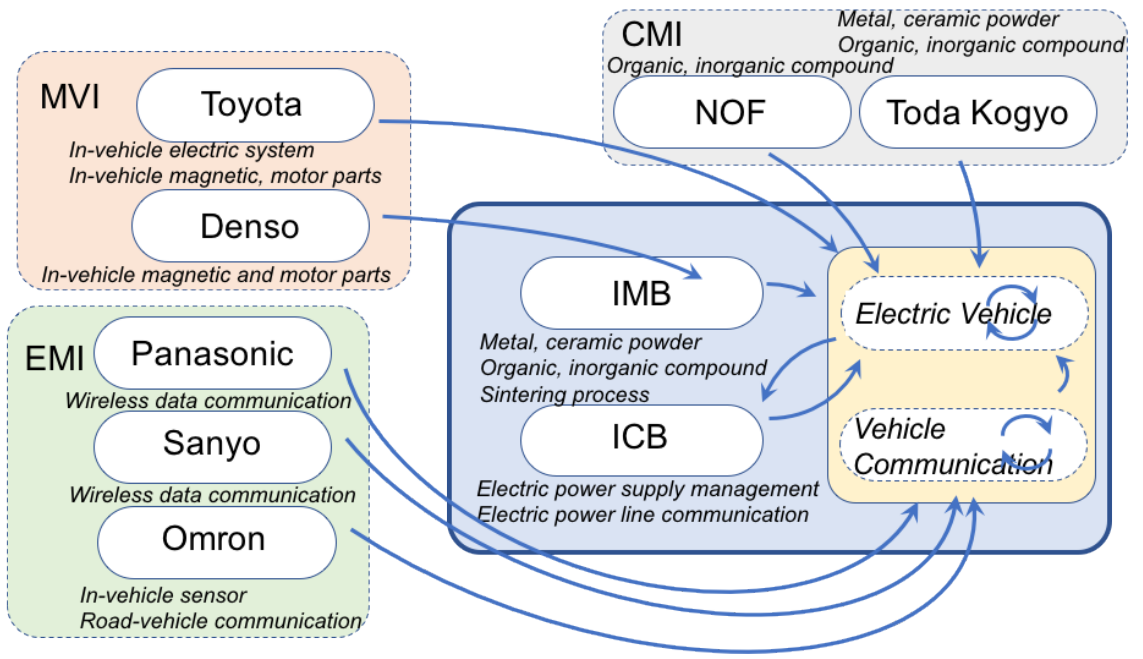

Figure 11: Multilayered technology spillover structure: organizations and technology

Nakagawa et al. remarked that the range of technology spillovers would expand along with the development of information communication technologies (Nakagawa et al., 2009). Moreover, in these cases, the range of technology spillovers not only expanded, but was also intricately superposed with various layers of organizations. Information communication technology moved its battlefield from a matured business unit (IMB, ICB) to developing business (AMB), from matured industry (EMI) to developing industry (MVI), where it can fight actively again. This succinctly explains how and why the automotive parts manufacturing firms have continuously made significant innovations.

Journal of Technology Management for Growing Economies, Volume 8, Number 1, April 2017
Roles of

Exogenous

Technologies in

Vehicle 


\section{Nakagawa, M. CONCLUSION}

Watanabe, $\mathrm{C}$

\section{New Findings}

New findings obtained through the analyses and discussions herein can be delineated thus:

(1) Technology spillovers from both inside and outside of a firm play important roles in technological innovation in growing automotive businesses.

(2) Incorporation of exogenous technologies by technology spillovers increases sales and operating income, which enables reinvestment in technology. Thus, a virtuous innovation cycle is operationalized.

(3) Technological innovation is enforced by simultaneous multilayered technology spillovers with organizational and technological facets.

\section{Implication}

Policy and practice implications for innovation managers, other relevant decision makers and wider stakeholders are important to stipulate and address in order that untapped potential and benefits are reaped as widely as possible. Technological innovation managers should focus attention (i.e., strategy and resources) to the construction, maintenance and optimization of virtuous cycles of innovation to obtain profit continuously by technological innovation. Further, our analysis has shown that as well as in-firm technologies, ex-firm technologies are also important for success. Moving on, active searching for technology spillover pools in various firms of various industries is required as various multilayered technology spillovers occur simultaneously. Finally, note that matured technologies in matured business domains are useful assets, ready for application to, and strengthening of, emerging business domains.

\section{ENDNOTE}

We have elucidated dynamism of technological innovation with respect to the growing motor vehicle industry, by analyzing microscopic infirm technology development. We confirmed that technology spillovers occur simultaneously on multilayers of an organization. These are the points for technological innovation managers to note.

At the end of this article, we should note limitations. First, this paper examines patents applied to Japan Patent Office; patents from 
outside Japan may be underestimated. Second, automotive-specialized firms, different from analyzed SEI, have not maintained electronics nor materials technologies inside; roles of intra-firm spillovers should be carefully reconsidered in those firms. Thirdly, big newcomers, such as Google, Apple, and Tesla, are not rooted to conventional motor vehicle industry; we should watch carefully whether and how our conclusions can be adopted. Finally, reactions between each spillover on different layers remain as a matter to be discussed. For instance, how and when do spillovers foster or hinder other types of spillover?

These issues can be subjects yet to be studied, connected with managerial strategy. Also, feedbacks from technology accepter to donor remain to be discussed.

\section{ACKNOWLEDGEMENT}

Authors would like to thank SEI for the collection of patent application data.

\section{APPENDIX}

Technology stock of an organization (firm or business unit) $i$ at time (year) $t$ can be expressed as (A-1) and (A-2).

$$
\begin{aligned}
& T_{i, t}=R_{i,\left(t-m_{i, t-1}\right)}+\left(1-\rho_{i, t-1}\right) T_{i, t-1} \\
& T_{i, 0}=\frac{R_{i\left(1-m_{i, 0}\right)}}{\rho+g_{i}} \\
& T_{i, t}: \text { technology stock of organization } \mathrm{i} \text { at time } \mathrm{t} \text {. } \\
& R_{i, t}: R \& \mathrm{D} \text { expenditure of organization } \mathrm{i} \text { at time t. } \\
& g_{i} \text { : increasing rate of R\&D expenditure of the early period (1993 to 1997) } \\
& g_{1}=0.124, g_{2}=-0.010, g_{3}=0.018, g_{4}=0.040, g_{5}=0.038 \\
& \rho_{i, t} \text { : obsolescence rate of organization } \mathrm{i} \text { at time } \mathrm{t} \text { and } m_{i, t} \text { :leading time from R\&D to its ouput are } \\
& \text { expressed as (A1-3) and (A1-4) (Watanabe, 1999). } \\
& \rho_{i, t}=0.03 e^{\left(\pi_{i, t} / \pi_{i, 0}\right)^{0.15}} \\
& m_{i, t}=-4.54 \ln \left(g_{i}+\rho_{i, t}\right)
\end{aligned}
$$

Figures A1 and A2 show trends in technology stock of SEI (by business unit), MVI, and EMI (1993-2014)

(Sources of R\&D expenditures: Statistics Bureau, Ministry of Internal Affairs and Communications Japan (1994-2015, annually), Sumitomo Electric Industries, Ltd. (1994-2015, annually) ) 
Nakagawa, M.

Watanabe, C.

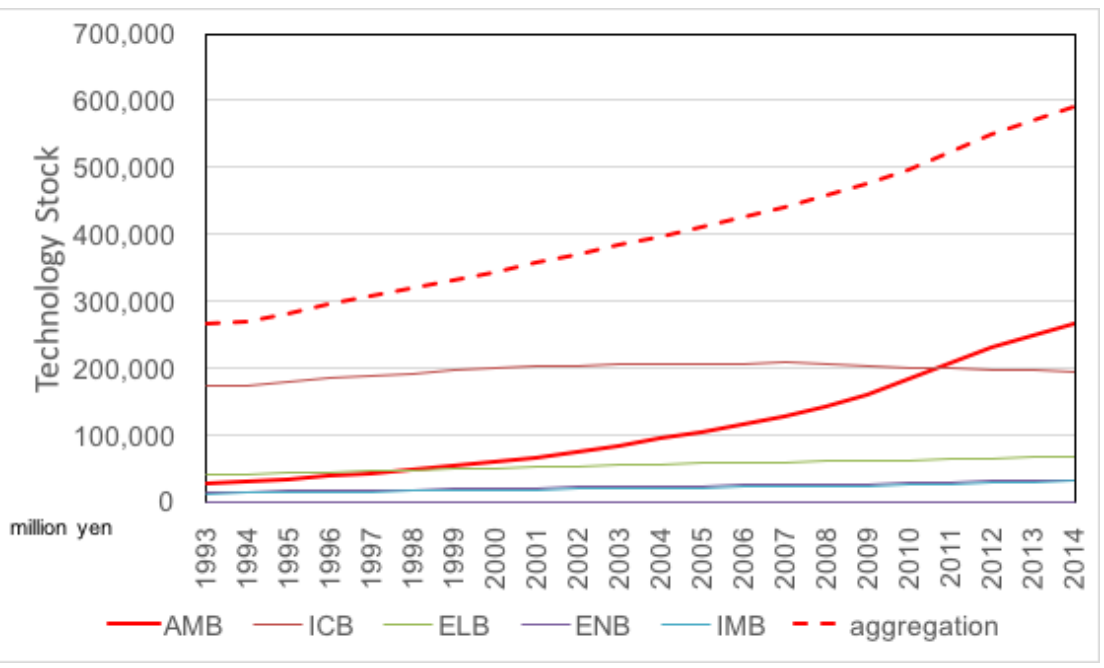

Figures A1: trends in technology stock of SEI (by business unit) (19932014).

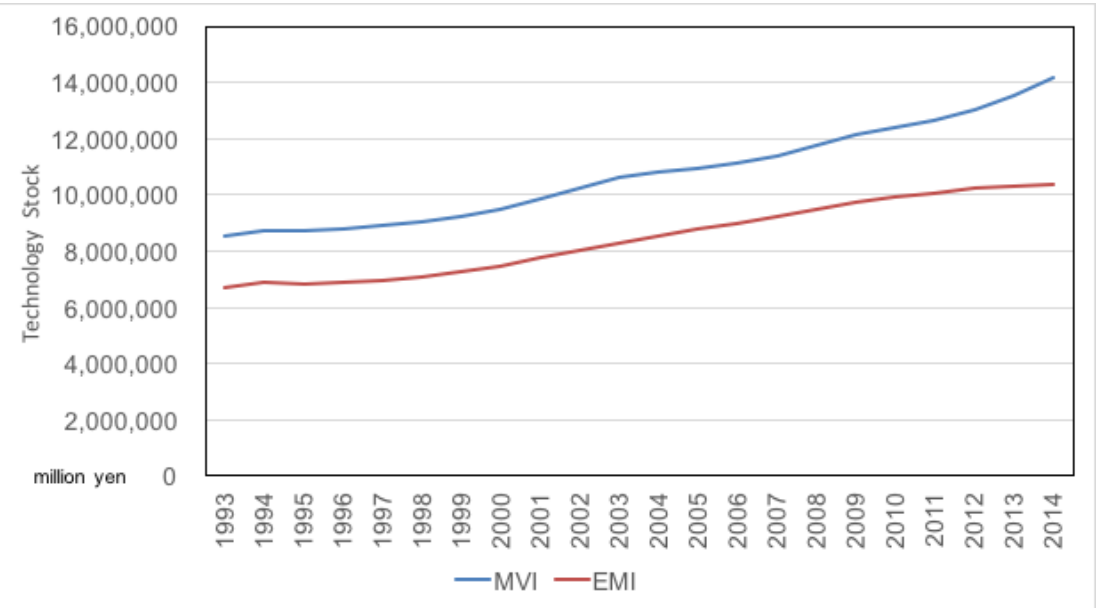

Figures A2: Trends in technology stock of MVI, and EMI (1993-2014). REFERENCES

Arora, A., Cohen, W.M., Walsh, J.P. (2016). The acquisition and commercialization of invention in American manufacturing: Incident and impact. Research Policy 45 (6) 113-1128. https://dx.doi.org/10.1016/j.respol.2016.02.005.

Bartel, A., Ichniowski, C., Shaw, K. (2007). How does information technology affect productivity? Plant-level comparisons of product innovation, process improvement and worker skills. Quarterly Journal of economics 122 (4) 1721-1758. https://dx.doi.org/10.1162/ qjec.2007.122.4.1721.

Battke, B. Schmit, T.S., Sitollenwerk, S., Hoffmann, F.H. (2016). Internal and external spill- 
overs-Which kind of knowledge is more likely to flow within or across technologies. Research Policy 45 (1) 27-41. https://dx.doi.org/10.1016/j.respol.2015.06.014.

Belderbos, R., Carree, M., Lokshin, B. (2004). Cooperative R\&D and company performance. Research Policy 33 (10) 1477-1492. https://dx.doi.org/10.1016/j.respol.2004.07.003.

Beneito, P. (2006). The innovative performance of in-house and contracted R\&D in terms of patents and utility models. Research Policy 35 (4) 502-517. https://dx.doi.org/10.1016/j. respol.2006.01.007

Bergek A., Berggren C., KITE Research Group (2014). The impact of environmental policy instruments on innovation: A Review of energy and AMB industry studies. Ecological Economics 106 112-123. https://dx.doi.org/10.1016/j.ecolecon.2014.07.016.

Bernstein, J. I. (1988). Costs of production, intra- and interindustry R\&D spillovers: Canadian evidence. The Canadian Journal of Economics 21 (2) 324-347.

Bloom, N., Schankerman, M., Van Reenen, J. (2013). Identifying technology spillovers and product market rivalry. Economitrica 81 (4) 1347-1393

Chesbrough, H.W. (2003). Open innovation. Massachusetts, MA: Harvard Business School

Christensen, J.F., Olesen, M.H., Kjær, J.S. (2005). The Industrial dynamics of open Innovation -Evidence from the transformation of consumer electronics. Research Policy 34 (10) 1533-1549.

Cortez, M.A.A., Cudia, C.P. (2011). The Virtuous cycles between environmental innovations and financial performance: Case study of Japanese AMB and electronics companies. Academy of Accounting and Financial Studies Journal 15 (2) 31-44.

Crispeels, T., Robert, D., Verbeke, W., Coosemans, T. van Mierio (2016). The development of hybrid electric vehicles: emergence and development of the patent network. World Electric Vehicle Journal 8 (3) 609-620.

Dosi, G., Nelson, R.R. (2010). Technical change and industrial dynamics as evolutionary processes. Handbook of the economics of innovation 1 (1C), 51-127. https://dx.doi. org/10.1016/S0169-7218(10)01003-8

Grillitsch, M. Trippl, M. (2014). Combining knowledge from different soueces, channels and geographical scales. European Planning Studies 22 (11) 2305-2325. http://dx.doi.org/10.1 080/09654313.2013.835793.

Grillitsh, M., Toedtling, F. Hoeglinger C. (2015). Variety in knowledge sourcing, geography and innovation: Evidence from the ICT sextor in Austria. Papers in Regional Science 94 (1) 25-43. http://dx.doi.org/10.1111/pirs.12050.

Hall, L. A., Bagchi-Sen S. (2002). A study of R\&D, innovaton, and business performance in the Canadian biotechnology industry. Technovation 22 231-244. https://dx.doi.org/10.1016/ S0166-4972(01)00016-5

Kato, T., Nunes, B., Dey, P.K. (2016). Is keiretsu really a source of competitive advantage for Japanese AMB suppliers? Journal of Manufacturing Technology Management 27 (1) 62-81.

Konno T. (2016). Network effect of knowledge spillover: Scale- free networks stimulate R\&D activities and accelerate economic growth. Physica A 458 157-167. https://dx.doi. org/10.1016/j.physa.2016.04.005.

Nakagawa, M., Watanabe, C. (2007). Moving beyond organizational inertia as a survival strategy for resource-based industry in a service-oriented economy: Lessons from cross-sector technology spillover in the nonferrous metal industry. Journal of Services Research 7 (1) 7-35.

Nakagawa, M., Watanabe, C., Griffy-Brown, C. (2009). Changes in the technology spillover structure due to economic paradigm shifts: A Driver of the economic revival in Japan's material industry beyond the year 2000. Technovation 29, 5-22. https://dx.doi.org/10.1016/j. technovation.2008.08.003.

Nakagawa, M., Watanabe, C. (2010). A revival of compound semiconductor material innovation: Strategic technology spillovers in Japan's nonferrous metal industry in the 2000s. Journal of Services Research 7 (1) 7-35. 
Nakagawa, M. Watanabe, $\mathrm{C}$.
Nakagawa, M., Watanabe. C. (2010). Innovation dynamics of materials technology: An empirical analysis and recommendation. Information Science Reference Intellectual Capital and Technological Innovation: Knowledge-Based Theory and Practice Eds. P. L. Saez, G. M. de Castro, J. E. N. Lopez, and M, Delgado-Verde Chapter 6,131-151.

Nakamura, M., Negoro, T. (2016). Layered structure of AMB industry by adopting information technologies-Three "Strategic layer models" of AMB industry. Working paper 2016 RIIM-WP-55, Research Institute of Information Technology and Management, Waseda Univ. in Japanese

Peters, J., Becker, W. (1997). Vertical corporate networks in the German automotive industry. International Studies of Management and Organization 27 (4) 158-185. http://dx.doi.org/1 $0.1080 / 00208825.1997 .11656722$.

Ruff, F. (2015). The advanced role of corporate foresight in innovation and strategic management-Reflections on practical experiences from the AMB industry. Technological Forecasting and Social Change 101 37-48. http://dx.doi.org/10.1016/j.techfore.2014.07.013.

Statistics Bureau, Ministry of Internal Affairs and Communications Japan (1994-2015, annually), Report on the survey of research and development. in Japanese

Sumitomo Electric Industries, Ltd. (1994-2015, annually) Financial Statement. in Japanese

Sumitomo Electric Industries, Ltd. (April 2001 - March 2015, monthly) SEI TODAY. in Japanese

Sumitomo Electric Industries, Ltd. (April 2001- March 2015, monthly) SEI WORLD. in Japanese

Veugelers, R. (1997). Internal R\&D expenditures and external technology sourcing. Research Policy 26 (3) 303-315. http://dx.doi.org/10.1016/S0048-7333(97)00019-x.

Volpato, G., Stocchetti, A. (2002). The Role of ICT in the strategic integration of the AMB supply-chain. International Journal of AMB Technology and Management 2 (3-4) 239-260

Watanabe, C. (1999). Systems option for sustainable development-Effect and limit of the ministry of international trade and industry's efforts to substitute technology for energy. Research Policy 28 719-749. https://dx.doi.org/10.1016/S0048-7333(99)00018-9.

Yun, J.H.J., Won, D., Jeong, E., Park, K.B., Yang, J.H., Park, J.Y. (2016) The Relationship between Technology, business model, and market in autonomous car and intelligent robot industries. Technological Forecasting and Social Change 103 142-155. https://dx.doi. org/10.1016/j.techfore.2015.11.016. 